\title{
A COMPARATIVE STUDY OF CUSTOMER SATISFACTION ON E-BANKING PRODUCTS IN ADDIS ABABA AND TRIVANDRUM
}

\author{
ESSAYAS TAYE LEMMA ${ }^{1} \&$ J. RAJAN ${ }^{2}$ \\ ${ }^{1}$ Research Scholar in Institutes of Management in Kerala (IMK) at University of Kerala, India \\ ${ }^{2}$ Professor and Dean, Faculty of Management studies, University of Kerala, India
}

\begin{abstract}
This study examines the impact of electronic banking products on customer satisfaction of commercial bank customers in Addis Ababa and Trivandrum cities. Due to the emergence of a global economy; electronic banking products have increasingly become an inevitable tool of banking business strategy and a strong catalyst for customer satisfaction. The main purpose of the study is comparing the impact of e-Banking products on customer satisfaction between Trivandrum and Addis Ababa city customers. The study was descriptive in nature and data gathered through questionnaires and document analysis. In order to achieve the objective of the study, mixed use sampling techniques were used. A sample size of the study was $(n=835)$. Data collected by structured questionnaire was an analysis of inferential statistics. The major results were the e-banking products have a significant difference in customer satisfaction on Trivandrum than Addis Ababa respondents. Based on these findings, conclusions were drawn and some feasible recommendations were made.
\end{abstract}

KEYWORDS: E-Banking Products, Customer Satisfaction, Addis Ababa \& Trivandrum

Received: Jul 10 12, 2017; Accepted: Jul 25, 2017; Published:Jul 31, 2017; Paper Id.: IJBMRAUG20175

\section{INTRODUCTION}

In any service suppliers and consumer relationship type of environment, satisfying a customer is the vital goal of the business. It is an important theoretical as well as a practical issue for most of the marketers and related to customer researchers because; organizations sometimes do not really understand what actually goes on in customers' mind (Fournier and Mick, 1999). The concept of customer satisfaction is equally important for service organizations, such as banks, Hotels, etc. As, many of them contribute to the fact that, higher customer satisfaction will lead to greater customer loyalty (Boulding et al., 1993), which in turn leads to future revenue. Hence, the concept of customer satisfaction not only means a happy customer, but rather more than that.

These days banks are using e-banking as a competitive tool to attract new customers, improve service quality and boost overall customer satisfaction. E-banking products are one of the tools that have created altered the way in which many industries conduct business. Banking is no exception to implement e-banking products as technology and innovative thinking to satisfy their customers.

Ever since the era of technology underway, people have found themselves to be more comfortable. Every organization is trying to be equipped in order to remain in the competition. The banking industry is like the other large organizations trying to be equipped with technology in order to remain in the competition. Furthermore, it is being kept on emerging at a large scale and increasing trend towards e-banking is one face of its emergence. The facility of e-banking gets more on demand when a customer from a busy environment does not have enough time 
to spare in going bank, stand in a long waiting queue to perform detailed banking activities or paying bills even (Hunjra, et, al., 2012). Besides, it even gets worse when a customer is intended to find out the working branch, want to operate for a transaction and find no access to it. Thus, e-banking products may make easy to transact business in the globe.

\section{STATEMENT OF THE PROBLEMS}

E-banking was executed by banks so as to improve their service delivery, decongest queues in the banking hall, enable customers withdraw cash 24/7, aid international payment and remittance, track personal banking transaction, request for online statement, or even transfer the deposit to a third party account. In spite of the effort of banks to ensure that customers reap the benefits of e-banking, the bank is met with grievances from customers as regards, malfunctioning Automated Teller Machines (ATMs), frequently breakdown network connection, online theft and fraud, non-availability of financial service, payment of the hidden cost of electronic banking like Short Message Services (SMS), for sending alerts, mandatory acquisition of ATM cards, non-acceptability of payment cards for international transaction amongst others. Therefore, this study is aimed at finding out the impact of e-banking products for the satisfaction of customers.

\section{OBJECTIVES OF THE STUDY}

The study seeks to:

- Examine the impact of e-banking products for customer satisfaction in Addis Ababa and Trivandrum;

- Compare the impact of e-banking products on customer satisfaction between Addis Ababa and Trivandrum city customers.

\section{HYPOTHESIS}

From the above Objectives, the followings were the hypothesis proposed in this study:

Ho1. There is no significant difference on the impact of e-banking products (ATM services, Mobile Banking, Internet Banking, Payment card and POS machine services) on customer satisfaction in Addis Ababa and Trivandrum.

\section{Sub-Hypothesis}

Ho1a: There is no significant difference in the impact of ATM machine services on customer satisfaction between Addis Ababa and Trivandrum.

Ho1b: There is no significant difference the impact of Mobile Banking on customer satisfaction between Addis Ababa and Trivandrum.

Ho1c: There is no significant difference the impact of Internet Banking on customer satisfaction between Addis Ababa and Trivandrum.

Ho1d: There is no significant difference the impact of Payment card on customer satisfaction between Addis Ababa and Trivandrum.

Ho1e: There is no significant difference the impact of POS machine services on customer satisfaction between Addis Ababa and Trivandrum. 


\section{SIGNIFICANCE AND SCOPE OF THE STUDY}

This will go a long way to help the banks achieve its stated objectives, and in the meantime increase shareholder's wealth. Besides, the study would enable banks executives and indeed the policy makers of the banks and financial institutions to be aware of electronic banking channels as a product of electronic commerce with a view to making strategic decisions. On top of that, it is essential to delimit the study from the standpoint of managing. Considering time limit, lack of finance to overcome the distance factor, this research was delimiting itself on Trivandrum and Addis Ababa city.

\section{E-BANKING IN INDIA}

Banking technology is emerging as synonymous with the concept of everyday banking. The competition among the banks has led to the growing total banking automation in the Indian banking industry. Finland was the first country in the world to have taken a lead in E-banking. In India, it was an ICICI bank, which initiated E-banking as early as 1997 under the brand name Infinity. A research that were studied on the Internet users, the result was found that about $23 \%$ of the online users prefer Internet Banking as the banking channel in India, second to the ATM which is preferred by 53\%. Out of the 6,365 Internet users sampled, 35\% use online banking channels in India (Kaur and Rajnecsh, 2014).

\section{E-BANKING IN ETHIOPIA}

The advent of E-banking in Ethiopia goes back to the late 2001, when the largest state owned, commercial bank of Ethiopia (CBE) introduced ATM to for domestic users. Despite being the forerunner in introducing ATM and acquired visa membership, CBE Lagged behind Dashen bank, which worked aggressively to maintain its lead in the E - payment system via ATM and other payment cards. Dashen Bank remains so far the only performer in the field of E-Banking since 2006 (Gardachew 2010).Zemen Bank, the only Ethiopian bank fastened in the idea of single branch banking, by launching a fullblown internet banking, a service which is new to the Ethiopian banking industry in the year 2010 (Ayana, 2014). Similarly, Awash International Bank S.C. Currently providing their bank service in the state art of technology. Bank of Abyssinia (BoA), the first privately owned commercial bank in the country, floated a tender to install Core Banking Solutions (CBS), a centralized system that networks, customer data in its 43 branches, 20 of which are in regional towns (BOA annual report, 2015/16).

\section{CUSTOMER SATISFACTION}

Customer satisfaction provides a leading indicator of consumer purchase intentions and loyalty (Farris, et.al. 2010). It is measured at the individual level, but it is almost always reported at an aggregate level. It can be, and often is, measured along various dimensions. In this study customer satisfaction of Trivandrum and Addis Ababa would be measure on e-banking product dimensions.

\section{MAJOR PRODUCTS OF E-BANKING PRODUCTS}

\section{ATM}

As banking services become universal and customers more sophisticated. With the majority of everyday transactions still based on cash, cash available at the ATM was the most important service measure especially for retail customers. The ATMs is emerging as the most useful tool to ensure, "Anytime Banking" and "Anywhere Banking" or "Anytime Money". The advent of the ATM has made the concept of round the clock banking a certainty. 


\section{Mobile Banking}

Mobile banking is considered as one of the most value added services in banking (Mahalakshmi, V., et. al., 2013). Facilities provided by mobile banking services have helped financial institutions to reduce traditional face-to-face banking transactions through automated services wherever possible. The customers in mobile banking services are increasing day by day due to seamless bank services that providing by the banks.

\section{Internet Banking}

Uses of Internet banking are as an efficient and viable tool to create customer value. It is one of the popular services offered by the traditional banks to provide speedier and reliable services to online users.

\section{Payment Card - Debit Card, ATM Cards, Credit Card,}

A payment card is a type of a payment instrument on which information is electronically recorded that used repeatedly for identification of the authorized users of payment services and for remote access to a payment account (https://abanksb.bg). In this research context, payment card includes credit cards, debit cards, Smart card, ATM card, etc.

\section{POS Machine Banking}

A POS (point of sale) can be referred as means any location where a sale or transaction may take place. For merchants, POS traditionally mean the area surrounding the cashier or counter where payment is accepted during checkout. Any form of payment can be used in POS machine, such as an ATM card, debit cards, credit cards etc.

\section{METHODOLOGY}

The descriptive research design was employed through survey approach. Both secondary and primary sources of data used in this study. The sample was used six banks' customers from Trivandrum city and five banks' customers in the Addis Ababa city were selected proportional to the total number of banks from the cities. For the present study one bank (State Bank of India) from Public bank and five banks (Federal Bank, ICICI Bank, Axis Bank, South Indian Bank and HDFC bank) from Private bank were chosen in Trivandrum. Meanwhile, in Addis Ababa one bank (Commercial Bank of Ethiopia) from Public and four banks (Awash International Bank, Dashen Bank, Bank of Abyssinia and Zemen Bank) were selected randomly.

The Addis Ababa city is stratified into ten sub-cities. Out of them, four were selected by using simple random sampling techniques (Arada, Bole, Kolfe-Keranyo and Ledeta sub-cities). Likewise, Trivandrum city is also stratified into six corporations. Out of which, three corporations were selected randomly. Namely; Attipra, Kadakampally and Fort were chosen randomly for this study. The number of respondents was selected and collected equally from each selected subcities and corporations.

Questionnaires were distributed for 900 respondents and 835 questionnaires were completed and used for the analysis. The questionnaires were administered through convenience sampling. Primary data were entered into the SPSS and analyzed by using inferential statistics.

\section{DATA ANALYSIS}

To arrive at results, data were collected with the help of questionnaires. The questionnaires were administered by paying for assistances. 


\section{Correlation Analysis}

The Pearson correlation coefficient was used to test the relationship between the variables. This particular type of analysis is useful when a researcher wants to establish if there are possible connections between variables (Overall Satisfaction, Satisfaction on POs, Satisfaction on Payment Card, Satisfaction on Internet Banking, Satisfaction on Mobile Banking and Satisfaction on ATM).

Table 1: Summary of Correlation Coefficients

\begin{tabular}{|c|c|c|c|c|c|c|c|}
\hline & & $\begin{array}{c}\text { Satisfaction } \\
\text { on ATM }\end{array}$ & $\begin{array}{c}\text { Satisfaction } \\
\text { in Mobile } \\
\text { Banking } \\
\end{array}$ & \begin{tabular}{|c|} 
Satisfaction \\
in Internet \\
Banking \\
\end{tabular} & $\begin{array}{c}\text { Satisfaction } \\
\text { on Payment } \\
\text { Card } \\
\end{array}$ & \begin{tabular}{|c|} 
Satisfaction \\
on PoS
\end{tabular} & \begin{tabular}{|c|} 
Overall, \\
My \\
Satisfaction \\
\end{tabular} \\
\hline \multirow{3}{*}{ Satisfaction on ATM } & $\begin{array}{l}\text { Pearson } \\
\text { Correlation }\end{array}$ & 1 & & & & & \\
\hline & Sig. (2-tailed) & & & & & & \\
\hline & $\mathrm{N}$ & 835 & & & & & \\
\hline \multirow{3}{*}{$\begin{array}{l}\text { Satisfaction in } \\
\text { Mobile Banking }\end{array}$} & $\begin{array}{l}\text { Pearson } \\
\text { Correlation }\end{array}$ & .192 & 1 & & & & \\
\hline & Sig. (2-tailed) & .099 & & & & & \\
\hline & $\mathrm{N}$ & 835 & 835 & & & & \\
\hline \multirow{3}{*}{$\begin{array}{l}\text { Satisfaction in } \\
\text { Internet Banking }\end{array}$} & $\begin{array}{l}\text { Pearson } \\
\text { Correlation } \\
\end{array}$ & .118 & -.088 & 1 & & & \\
\hline & Sig. (2-tailed) & .313 & .455 & & & & \\
\hline & $\mathrm{N}$ & 835 & 835 & 835 & & & \\
\hline \multirow{3}{*}{$\begin{array}{l}\text { Satisfaction on } \\
\text { Payment Card }\end{array}$} & $\begin{array}{l}\text { Pearson } \\
\text { Correlation }\end{array}$ & $.309^{* *}$ & $.726^{* *}$ & .196 & 1 & & \\
\hline & Sig. (2-tailed) & .007 & .000 & .092 & & & \\
\hline & $\mathrm{N}$ & 835 & 835 & 835 & 835 & & \\
\hline \multirow{3}{*}{ Satisfaction on PoS } & $\begin{array}{l}\text { Pearson } \\
\text { Correlation }\end{array}$ & $.242^{*}$ & $.734^{* *}$ & .214 & $.821^{* *}$ & 1 & \\
\hline & Sig. (2-tailed) & .036 & .000 & .065 & .000 & & \\
\hline & $\mathrm{N}$ & 835 & 835 & 835 & 835 & 835 & \\
\hline \multirow{3}{*}{$\begin{array}{l}\text { Overall, my primary } \\
\text { bank provides } \\
\text { excellent e-Banking } \\
\text { services }\end{array}$} & $\begin{array}{l}\text { Pearson } \\
\text { Correlation }\end{array}$ & $.353^{* *}$ & $.743^{* *}$ & $.253^{*}$ & $.794^{* *}$ & $.802^{* *}$ & 1 \\
\hline & Sig. (2-tailed) & .002 & .000 & .028 & .000 & .000 & \\
\hline & $\mathrm{N}$ & 835 & 835 & 835 & 835 & 835 & 835 \\
\hline
\end{tabular}

Source: Survey data

According to the Table 2, there is a significant positive relationship between the five types of e-banking products and customer satisfaction, the highest correlation is between POS machine services and customer satisfaction (0.802); followed by Payment Card (0.794), Mobile Banking (0.743) and ATM services (0.343) respectively with significant at the 0.01. The weakest correlation is between Internet Banking and customer satisfaction (0.253) with significant at the 0.05. Because the correlation was positive, types of e-banking products and customer satisfaction is positively related, which means the highly accepted e-banking products was the highest customer satisfaction. Accordingly, the most important ebanking products that affect customer satisfaction is POS machine service, which goes to prove that POS perceived as a dominant product followed by Payment card; indicating improvements in customers' satisfaction levels were significant. It implies that customers are preferred to buying goods and service without carrying paper money in shops.

\section{Analysis of E-Banking Products}

Now-a-days Banks are providing convenient and innovative e-banking products and services to drive customer 
satisfaction, business growth and seamless management of business processes. Deploy of the latest technology is helping to ensure efficient service delivery using the context of e-banking products or channels. The most common types of e-banking products or channels and that studying in this research is suite of cards and channels. Such as ATM, Mobile Banking, Internet Banking, Payment card and POS machines were selected for this study.

Thus, as the main objective of the research was to find out the difference of customer satisfaction with e-Banking product types between Trivandrum and Addis Ababa customers. In light of this to meet the objective of the study, it's hypothesized that:

Ho3. There is no significant difference between e-Banking product types of customer satisfaction in Trivandrum and Addis Ababa.

Concerning with analysis tools, an independent-samples t-test was conducted to compare customer satisfaction of e-banking products related to ATM services between Trivandrum and Addis Ababa respondents.

Table 2: Independent SAMPLE T-Test on ATM services Variables (Group Statistics)

\begin{tabular}{|c|c|c|c|c|c|c|}
\hline Items & $\begin{array}{c}\text { Data Collection } \\
\text { Country/City }\end{array}$ & $\mathbf{N}$ & Mean & $\begin{array}{c}\text { Std. } \\
\text { Deviation }\end{array}$ & T-Test & $\begin{array}{r}\text { Sig. }(2 \\
\text { Tailed }) \\
\end{array}$ \\
\hline \multirow{2}{*}{ Satisfaction on ATM } & Addis Ababa & 410 & 3.9889 & .81127 & \multirow{2}{*}{.192} & \multirow{2}{*}{0.848} \\
\hline & Trivandrum & 425 & 3.9487 & .98164 & & \\
\hline \multirow{2}{*}{ Satisfaction in Mobile Banking } & Addis Ababa & 410 & 2.8222 & .64636 & \multirow{2}{*}{-6.044} & \multirow{2}{*}{0.000} \\
\hline & Trivandrum & 425 & 3.7795 & .71935 & & \\
\hline \multirow{2}{*}{ Satisfaction in Internet Banking } & Addis Ababa & 410 & 2.7111 & .46216 & \multirow{2}{*}{-1.629} & \multirow{2}{*}{0.108} \\
\hline & Trivandrum & 425 & 2.8821 & .44655 & & \\
\hline \multirow{2}{*}{ Satisfaction on Payment Card } & Addis Ababa & 410 & 2.4778 & .53937 & \multirow{2}{*}{-10.444} & \multirow{2}{*}{0.000} \\
\hline & Trivandrum & 425 & 4.1231 & .79022 & & \\
\hline \multirow{2}{*}{ Satisfaction on POS } & Addis Ababa & 410 & 2.7222 & .47154 & \multirow{2}{*}{-10.698} & \multirow{2}{*}{0.000} \\
\hline & Trivandrum & 425 & 4.1231 & .64173 & & \\
\hline
\end{tabular}

Source: survey data

\section{Testing Sub-Hypothesis}

Ho3a: There is no significant difference between level of customer satisfaction of e-Banking products in Trivandrum and Addis Ababa related to ATM service.

An independent-samples t-test was conducted to compare customer satisfaction of e-banking products related to ATM services between Trivandrum and Addis Ababa respondents. There was an insignificant difference in the overall satisfaction on ATM service scores for Addis Ababa $(\mathrm{M}=3.99, \mathrm{SD}=0.811)$ and Trivandrum $(\mathrm{M}=3.94, \mathrm{SD}=0.981)$ conditions; t-test 0.192 and the $\mathrm{p}$ - value is 0.848 at $5 \%$ level of significant ( $\mathrm{p}>0.05$ ). It implies that ATM services in both cities are urged on by a huge uptake by customers. Furthermore, these results suggest that Addis Ababa customers are more satisfied than Trivandrum customers. Therefore, the analysis of the ATM service satisfaction indicates that there has found insignificant differences between Trivandrum and Addis Ababa. On this basis, the null Hypothesis (H2b) is Accepted.

Ho3b: There is no significant difference between level of customer satisfaction of e-Banking products in Trivandrum and Addis Ababa related to Mobile Banking;

It is clearly shown on the above table 1; customer satisfaction of e-banking products specific to Mobile Banking has been a significant difference between Trivandrum and Addis Ababa respondents. Mean scores for Addis Ababa $(\mathrm{M}=2.88, \mathrm{SD}=0.656)$ less satisfied than Trivandrum $(\mathrm{M}=3.78, \mathrm{SD}=0.720)$. With this condition, the $\mathrm{t}$-values show large 
values, which was -6.044 and p-value was 0.000 that is less than 0.05 . It means there is a significant difference on Mobile Banking service, customer satisfaction between Trivandrum and Addis Ababa. It implies that the mobile technology to support banking business less in Addis Ababa comparing to Trivandrum. It may be the problems of country infrastructure facilities. From this result, the null hypothesis (Ho3b) is standing for rejected.

Ho3c: There is no significant difference between level of customer satisfaction of e-Banking products in Trivandrum and Addis Ababa related to Internet Banking;

From the above table 2, it is inferred overall satisfaction with the Internet Banking service that the p-value 0.108 is greater than 0.05 and t-values -1.629 with the condition mean score value for Addis Ababa $(\mathrm{M}=2.711, \mathrm{SD}=0.462)$ and Trivandrum $(\mathrm{M}=2.88, \mathrm{SD}=0.45)$. It means and there is no significant difference between level of customer satisfaction of Internet Banking in Trivandrum and Addis Ababa. Moreover, even if both cities are dissatisfied the mean values clearly show that Addis Ababa customers are more dissatisfied than Trivandrum. The result implies that an internet facility is common problems for both cities. From this result, the null hypothesis (Ho3c) is standing for Accepted.

Ho3d: There is no significant difference between level of customer satisfaction of e-Banking products in Trivandrum and Addis Ababa related to Payment Card;

As inferred the above table 1 data, there is no statistical evidence to support the above hypothesis (Ho3d). The test is satisfaction on payment cards confirmed on the value of t-test, that was indicated -10.444and the p- values was shown 0.000 at the $5 \%$ level of significance $(\mathrm{p}<0.05)$ meanwhile, the mean score shows in Addis Ababa $(\mathrm{M}=2.48, \mathrm{SD}=0.54)$ and Trivandrum $(\mathrm{M}=4.12, \mathrm{SD}=0.79)$. Therefore, the analysis on the e-banking products regarding with payment card dimension indicates that there was found significant differences between Trivandrum and Addis Ababa. It implies that number of payment card did not well distributed in Addis Ababa due to infrastructure and awareness problems. On this basis, the null Hypothesis (Ho3b) stands for rejected.

Ho3e: There is no significant difference between level of customer satisfaction of e-Banking products in Trivandrum and Addis Ababa related to POS Machine services;

Likewise, the sub - hypothesis (Ho3d) - the customers are satisfied with the bank provided POS Machine service, was put to statistically test by using independent sample $\mathrm{t}$ - test as significant. There was a significant difference in the overall satisfaction in POS Machine service scores for Addis Ababa $(\mathrm{M}=2.72, \mathrm{SD}=0.47)$ and Trivandrum (M=4.12, $\mathrm{SD}=0.64)$ conditions; t-test -10.698 and the $\mathrm{p}$ - values are 0.000 at the $5 \%$ level of significance $(\mathrm{p}<0.05)$. It implies that POS Machine service are better practiced and disseminated in Trivandrum than Addis Ababa. Moreover, these results suggest that Addis Ababa customers are less satisfied than Trivandrum customers. It implies Trivandrum customers are ongoing there practice into paperless transactions. Therefore, the analysis of the POS Machine service satisfaction indicates that there has found significant differences between Trivandrum and Addis Ababa. On this ground, the null Hypothesis $(\mathbf{H} 2 \mathrm{~b})$ is rejected.

\section{CONCLUSIONS AND SUGGESTIONS}

The customer satisfaction is the major factor contributing to the success of service sectors. E-banking has become a crucial system and is fundamentally changing the banking industry worldwide. The result of the study also shows that ebanking products have a positive impact on customer satisfaction. However, when comparing the two cities customers' satisfaction on e-banking products that they have significant differences in Mobile banking, Payment card and POS 
machine service. Whereas, ATM service and Internet banking service were insignificant difference, which is both Trivandrum and Addis Ababa customers were satisfied with ATM service and dissatisfied on Internet banking with different levels. Therefore, banker and e-banking service designers should think over these types of e-banking products to customize the product in the country context. And make possible changes on e-banking products according to the customers' expectations and need of the period. It will help to enhance the level of customers' satisfaction with e-banking.

\section{REFERENCES}

1. Fournier, S. and Mick, D.G. (1999).Rediscovering satisfaction. Journal of Marketing, 63(3), 5-23.

2. Boulding, W., Kalra, A., Staeling, R., and Zeithaml, V.A. (1993). A dynamic process model of service quality: From expectation to behavioural intentions. Journal of Marketing Research, 30(1), 7-27.

3. Hunjra, A. I., Ali, A. \& Anwar, S. (2012). The Impact of E-Banking on Customer Satisfaction: A Comparative Analysis on Pakistani Banking Sector. Bulletin of Business and Economics, 1(1), 1-43.

4. www.rbi.com (RBI report, 2016)

5. www.nbe.com (NBE report, 2016)

6. Farris, Paul W.; Neil T. Bendle; Phillip E. Pfeifer; David J. Reibstein (2010). Marketing Metrics: The Definitive Guide to Measuring Marketing Performance. Upper Saddle River, New Jersey: Pearson Education, Inc. ISBN 0-13-705829-2.

7. https://abanksb.bg/en/about-the-main-bank.../payment-cards-and-electronic-banking.

8. Mahalakshmi V., Saravanaraj, M., and Umarani, T., (2013).Customers' perception about value added services rendered by banks. African Journal of Business Management. Vol. 7(29), pp. 2845-2851.

9. Gardachew 2010). Electronic -banking in Ethiopia: practices, opportunities and Challenges. Journal of internet Banking and commerce, 15(2):2-9

10. Ayana, G., (2014). Factors Affecting Adoption of Electronic Banking System in Ethiopian Banking Industry. Journal of Management Information System and E-commerce Vol. 1, No. 1; June 2014

11. BOA annual report (2016). Bank of Abyssinia annual report 2015/16.

12. Kaur, K., and Rajnecsh. (2014). International Journal of Management and Commerce Innovations ISSN $2348-7585$ (Online) Vol. 2, Issue 1, pp: (86-93), Month: April 2014 - September 2014, Available at: www.researchpublish.com 